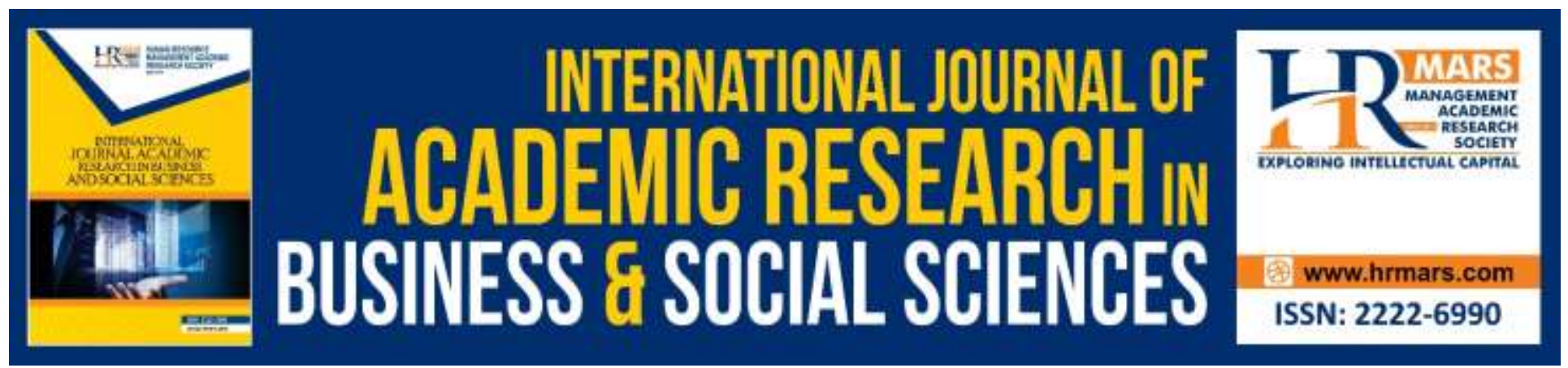

\title{
Preliminary Survey on Availability of Local Skilled Construction Workers at Construction Sites
}

Norazlin Mat Salleh, Nor Suzila Lop, Shahela Mamter, Zaiwannizar Zainal Abidin

To Link this Article: http://dx.doi.org/10.6007/IJARBSS/v10-i3/7077

DOI:10.6007/IJARBSS/v10-i3/7077

Received: 03 February 2020, Revised: 23 February 2020, Accepted: 13 March 2020

Published Online: 29 March 2020

In-Text Citation: (Salleh et al., 2020)

To Cite this Article: Salleh, N. M., Lop, N. S., Mamter, S., \& Abidin, Z. Z. (2020). Preliminary Survey on Availability of Local Skilled Construction Workers at Construction Sites. International Journal of Academic Research in Business and Social Sciences, 10(3), 618-632.

\section{Copyright: (C) 2020 The Author(s)}

Published by Human Resource Management Academic Research Society (www.hrmars.com)

This article is published under the Creative Commons Attribution (CC BY 4.0) license. Anyone may reproduce, distribute, translate and create derivative works of this article (for both commercial and non-commercial purposes), subject to full attribution to the original publication and authors. The full terms of this license may be seen

at: http://creativecommons.org/licences/by/4.0/legalcode

\section{Vol. 10, No. 3, 2020, Pg. 618 - 632}

http://hrmars.com/index.php/pages/detail/IJARBSS

JOURNAL HOMEPAGE

Full Terms \& Conditions of access and use can be found at http://hrmars.com/index.php/pages/detail/publication-ethics 


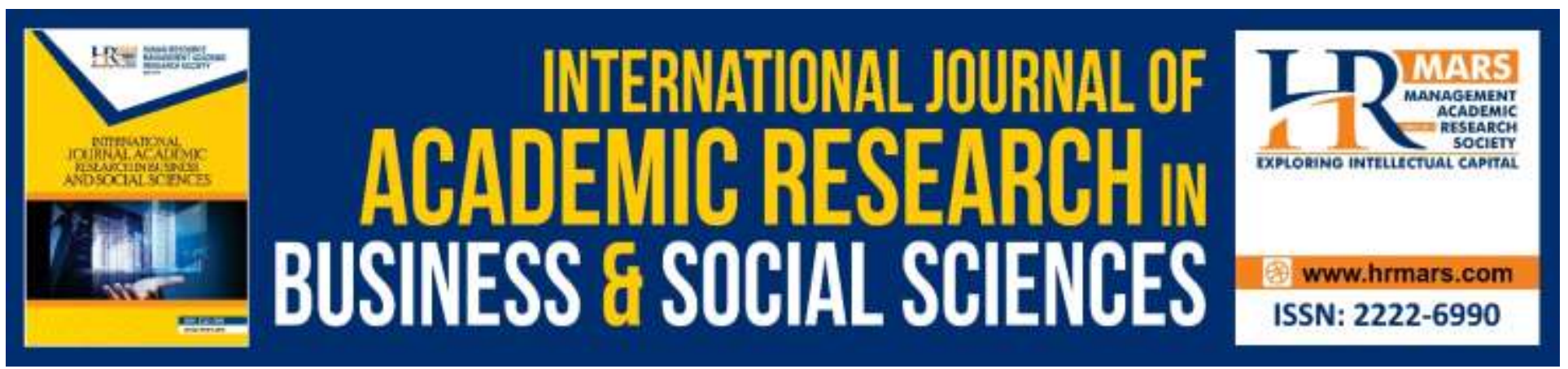

\title{
Preliminary Survey on Availability of Local Skilled Construction Workers at Construction Sites
}

\author{
Norazlin Mat Salleh, Nor Suzila Lop, Shahela Mamter, Zaiwannizar \\ Zainal Abidin \\ Department of Quantity Surveying, Faculty of Architecture Planning and Surveying, Universiti \\ Teknologi MARA (Perak), Malaysia \\ Email: noraz470@perak.uitm.edu.my
}

\begin{abstract}
A scenario of the Malaysian construction industry is moving towards the realisation of industrial revolution agenda 4.0. Thus, new technologies have been introduced to support the industry. However, specific tasks still required labours to perform the work. The use of labour is a primary factor in the production of a building. Nevertheless, the difficulties to employ local skilled workers to meet the industry demand is significance. Although there are many Technical and Vocational Education Training (TVET) institutions that produce graduates in the field of construction related course, nonetheless, some of them are reluctant to join the construction sector because of the 3D's (dirty, dangerous and difficult) environment of the industry. Consequently, most of the employer tend to hire unskilled foreign workers in their projects. This shortage of local labour has become one of the factors that affect the development of this country. Thus, it is vital to identify the number of local skilled construction workers available at construction sites and to determine the current labour issues at construction sites. The semi-structured interview has been conducted with the site supervisors at five random construction sites. The data was analysed using a qualitative software (i.e Atlas.ti@8).Four issues that are related to hiring of local skilled labour in construction project; as local labours request for higher wages, demand to work at the supervisory level, incompliance with industry regulations and the employers' expectation of high skills and experience from the labour. The outcomes of this paper can serve as a foundation for the construction stakeholders in addressing the problems of labour shortage in Malaysia.
\end{abstract}

Keywords: Construction, Workers, Skilled Labour, Construction, Sites.

\section{Introduction}

The construction industry is one of the industries that contribute to the development of a country. It plays a vital role in all major industrial sectors of a country in the form of fixed capital, services, housing and others. Physically, the output of the construction industry is large, heavy, expensive and 
INTERNATIONAL JOURNAL OF ACADEMIC RESEARCH IN BUSINESS AND SOCIAL SCIENCES Vol. 10, No. 3, March, 2020, E-ISSN: 2222-6990 @ 2020 HRMARS

immovable. It involves the use of a variety of building materials and components manufactured by other manufacturing industries. The construction output consists of various types of buildings, civil engineering works and infrastructure works. It is very segmented process and stages. Various parties involved in each activity commencing from inception until the feedback stage and extended to the end of life of the building. One of the essential participants in the construction process is a worker. Without them the mission of the construction project will not be accomplished. Generally, up to forty percent of labour cost constituted to the total construction project costs. Their contributions are indispensable to ensure that all task given is carried out according to clients' requirement (Odesola and Idoro, 2014)

The role of higher education institution in producing the competence local skilled labour to meet the industry demand (Triki, 2010). Focusing on that, Malaysian Technical and Vocational Education Training's (TVET) institutions are responsible in providing skilled workers for construction sector. Recently, Malaysia has developed numerous TVET institutions in providing highly skilled workers. Nevertheless, CIDB (2015) and Mohd Rahim (2016) pointed out, that the construction remains claimed shortage of skilled workers to fill the vacancies in the construction sites. The constraints of construction projects are time, cost and quality. As a result, the employers would hire unskilled foreign workers to execute all the works on site. Numerous studies conducted have demonstrated that there was a shortage of local skilled workers to meet the industry demands as reported by (Jamil and Yusof, 2011; Abdullah et al., 2015; Mohamed, 2015; Majid et al., 2015; Hussien, 2016; Mohd Rahim et al., 2016). In addition to that, Abdul Hamid (2013) found that the composition of labour in one construction project were $82.77 \%$ of the workers are foreign labours mostly from Indonesia and only $17.23 \%$ were local labours which is less than one fifth of the total number of labours in the construction project. In view of the above scenario, this research was aimed, to identify the availability of local skilled construction workers at construction sites. In line with this aim, two objectives were further established, there are; to identify the statistics of local skilled construction workers available at construction sites and to determine the current labour issues occurrence at construction sites.

\section{Literature Review}

\section{Labour in Malaysia Construction Industry}

The major impact to Malaysian construction projects came from the implementation of 24 major projects costing more than RM1.0 billion each. These projects accounts for RM109.9 billion in 2016. The five largest projects were: 1. East Coast Rail Link from Port Klang, Selangor to Wakaf Bahru, Kelantan. Award: November 2016; Expected completion: 2024. 2. Mass Rapid Transit Sungai Buloh Serdang - Putrajaya Line (Jalan Ipoh North Escape Shaft to Desa Waterpark South Portal) in Klang Valley. Award: March 2016; Expected completion: 2021 3. Electrified Double Track (Gemas to Johor Bahru) in Johor. Award: October 2016; Expected completion: 2020 4. 1,800MW to 2,400MW Combined Cycle Gas Turbine Power Plant in Alor Gajar, Melaka. Award: November 2016; Expected completion: 2021 5. Setiawangsa - Pantai Expressway in Kuala Lumpur. Award: November 2016; Expected completion: 2020 (CIDB, 2017).

All these megaprojects will require skilled, semi-skilled and general construction workers from various trades of work. CIDB act 520 stated the definition of each is "general construction worker" 
INTERNATIONAL JOURNAL OF ACADEMIC RESEARCH IN BUSINESS AND SOCIAL SCIENCES Vol. 10, No. 3, March, 2020, E-ISSN: 2222-6990 @ 2020 HRMARS

means any employee or class of employee who is not skilled and who is engaged in manual work; "semi-skilled construction worker" means any employee possessing the accepted level of skill, knowledge, qualification and experience of one or more of the trades as determined by the Board; "skilled construction worker" means any employee possessing the accepted level of skill, knowledge, qualification and experience of one or more of the trades as determined by the Board. Nasir et al. (2011) defined that, Skilled worker is deemed to be the person who acquired skills or knowledge related to the skills from recognized tertiary level institutions and use their skills with good application and beneficial to all parties. In addition, according to Jabatan Pembangunan Kemahiran, a skilled worker is a worker with level 3 of Sijil Kemahiran Malaysia (SKM) as a minimum qualification.

According Bheemaiah and Smith (2015), skilled worker is a segment of the work force with a high skill level that creates significant economic value through the work performed. The skilled worker is generally characterised by high experience and expertise level and involved in complicated tasks that require specific skill sets, education, training and experience, and may involve abstract thinking. Sweet and Meiksins (2017) added that, a skilled worker requires some forms of professionalism and training which does not require a college degree or the like. Common skilled workers include electrician, plumber, painter, carpenter and mason, bar bender, tiller, plant operator, welder, mechanics, and steel fixer (Uchitelle, 2009).

In Malaysia, the skilled construction workers provided by Technical, Vocational Education and Training (TVET) institutions. TVET includes formal, non-formal and informal learning that prepares young people with the knowledge and skills required in the world of work. According to the United Nations Organisation for Education, Science and Culture (UNESCO), the term TVET has been used interchangeably, i.e. apprenticeship training, vocational education, technical education, technicalvocational education, occupational education, vocational education and training, professional and vocational education, career and technical education, workforce education, workplace education, and others. Importantly, the common features of TVET as defined by UNESCO is similar which involves "in addition to general education, the study of technologies and related sciences as well as the acquisition of practical skills, attitudes, understanding, and knowledge relating to occupations in various sectors of economics and social life". In TVET, young people have the opportunity to learn from basic to advanced levels across a wide range of institutional and work settings (Mike, 2015). There are many TVET institutions offered related construction course as listed in Table 1. One of them is Malaysian Construction Academy ( $A B M)$. ABM is a CIDB assessment and training centre, which caters to the need for skills development and development for construction workers. ABM focuses on equipping building personnel with industry-standard competence according to industry standards. There are four centres in Peninsular Malaysia and two at Sabah and Sarawak. 
INTERNATIONAL JOURNAL OF ACADEMIC RESEARCH IN BUSINESS AND SOCIAL SCIENCES Vol. 10, No. 3, March, 2020, E-ISSN: 2222-6990 (C) 2020 HRMARS

Table 1: List of Public Training Institutes in Malaysia

\begin{tabular}{|c|c|c|c|c|}
\hline No. & Ministry & Public Training Institute & $\begin{array}{c}\text { No. of } \\
\text { Institute }\end{array}$ & Capacity \\
\hline \multirow[t]{4}{*}{1} & \multirow{3}{*}{$\begin{array}{l}\text { Ministry of Human } \\
\text { Resources }\end{array}$} & Industrial Training institute & 23 & 15,160 \\
\hline & & $\begin{array}{l}\text { Advanced Technology Training } \\
\text { Centre }\end{array}$ & 8 & 6,100 \\
\hline & & $\begin{array}{l}\text { Japan-Malaysia } \quad \text { Training } \\
\text { Institute }\end{array}$ & 1 & 800 \\
\hline & Total & & 32 & 22,060 \\
\hline \multirow[t]{4}{*}{2} & \multirow[t]{3}{*}{ Ministry of Education } & Polytechnic & 33 & 89,000 \\
\hline & & Community College & 91 & 32,470 \\
\hline & & Vocational College & 80 & 15,384 \\
\hline & Total & & 204 & 139,230 \\
\hline \multirow[t]{2}{*}{3} & $\begin{array}{l}\text { Ministry of Women, } \\
\text { Family } \\
\text { Community } \\
\text { Development }\end{array}$ & $\begin{array}{l}\text { Industrial Training and } \\
\text { Rehabilitation Centre }\end{array}$ & 1 (OKU) & 300 \\
\hline & Total & & 1 & 300 \\
\hline \multirow[t]{4}{*}{4} & \multirow{3}{*}{$\begin{array}{l}\text { Ministry of Rural and } \\
\text { Regional Development }\end{array}$} & MARA Training Institute & 13 & 13,162 \\
\hline & & $\begin{array}{l}\text { MARA Higher Skill College } \\
\text { (KKTM) }\end{array}$ & 10 & 9,976 \\
\hline & & GiatMARA & 231 & 23,000 \\
\hline & Total & & 254 & 46,138 \\
\hline \multirow[t]{3}{*}{5} & \multirow[t]{2}{*}{$\begin{array}{l}\text { Ministry of Youth and } \\
\text { Sport }\end{array}$} & $\begin{array}{l}\text { National Youth Higher Skills } \\
\text { Institute (IKTBN) }\end{array}$ & 1 & 600 \\
\hline & & $\begin{array}{l}\text { National Youth Skills Institute } \\
\text { (IKBN) }\end{array}$ & 19 & 15,640 \\
\hline & Total & & 20 & 15,640 \\
\hline \multirow[t]{2}{*}{6} & $\begin{array}{l}\text { Construction Industry } \\
\text { Development Board } \\
\text { (CIDB), Ministry of } \\
\text { Public Work }\end{array}$ & $\begin{array}{ll}\text { Malaysian } & \text { Construction } \\
\text { Academy (ABM) } & \end{array}$ & 6 & 6000 \\
\hline & Total & & 6 & 6000 \\
\hline
\end{tabular}

Source: Ministry of Human Resources

Table 2 shows the construction workers completed their training at ABM in 2012 until 2016. The trainee conducts various types of training in building (bricklayer, concreter, plumber, bar bender, carpenter and painter), Industrial Building System (IBS), crane operation, plant operation, mechanical and electrical. It demonstrates that the availability of local skilled construction workers to enter the industry. 
INTERNATIONAL JOURNAL OF ACADEMIC RESEARCH IN BUSINESS AND SOCIAL SCIENCES Vol. 10, No. 3, March, 2020, E-ISSN: 2222-6990 @ 2020 HRMARS

Table 2: Skilled Construction Workers from Malaysian Construction Academy (ABM, 2017)

\begin{tabular}{lcccccc}
\hline ABM Campus & $\mathbf{2 0 1 2}$ & $\mathbf{2 0 1 3}$ & $\mathbf{2 0 1 4}$ & $\mathbf{2 0 1 5}$ & $\mathbf{2 0 1 6}$ & TOTAL \\
\hline Centre & 2,224 & 3,411 & 4,229 & 4,347 & 5,154 & 19,365 \\
\hline Eastern & 2,530 & 2,530 & 3,123 & 2,654 & 4,729 & 15,566 \\
\hline Northern & 2,816 & 2,816 & 4,104 & 4,638 & 4,748 & 19,122 \\
\hline Southern & 2,206 & 2,206 & 4,143 & 3,272 & 4,559 & 16,386 \\
\hline Sarawak & 1,950 & 1,950 & 3,196 & 5,171 & 4,711 & 16,978 \\
\hline Sabah & 3,489 & 3,489 & 5,530 & 6,076 & 5,436 & 24,020 \\
\hline TOTAL & 15,215 & 16,402 & 24,325 & 26,158 & 29,337 & 111,437 \\
\hline
\end{tabular}

Source: Construction Industry Development Board, Malaysia

The statistic shows that, it should not be a problem for employers to hire local skilled workers. There are many other TVET institutions in Malaysia offered construction related courses as previously presented in Table 1 in order to accommodate the local labours to enter the construction industry. The availability of skilled workers graduated from the institutions can fill the vacancies in the market. Table 3 presents the registration of construction personnel by category of worker in year 2015 and 2016. It shows that, there are many of local workers have been hired as compared to the foreign workers. Nevertheless, in reality, the construction site has been dominated by foreign workers working without legitimate registration. The statistics presented by most of the agencies does not reflect the actual situation at the construction site where Malaysia's dependence on foreign workers is very high (Mohamed, 2015). The statistics from the Immigration Department of Malaysia, in 2017 showed a total of 1.7 million foreign workers recruit in the country. Based on the Ministry of Home Affairs, Indonesia had the highest foreign workers of 728,870 people followed by Nepal $(405,898)$, Bangladesh (221,089), Myanmar (127,705), India $(114,455)$, Pakistan $(59,281)$ and Vietnam $(29,039)$. There are also workers from China $(15,399)$, Thailand $(12,603)$, Sri Lanka $(5,964)$, Cambodia $(5,103)$ and Laos (39) (Nazura Ngah et al., 2017).

Table 3: Registered Construction Personnel by Category of Worker

\begin{tabular}{|c|c|c|c|c|}
\hline \multirow[t]{2}{*}{ Category of Worker } & \multicolumn{2}{|c|}{2015} & \multicolumn{2}{|c|}{2016} \\
\hline & Local & Foreign & Local & Foreign \\
\hline Construction worker & 295,560 & 135,997 & 304,167 & 148,025 \\
\hline $\begin{array}{l}\text { Skilled construction } \\
\text { worker }\end{array}$ & 50,855 & 1,675 & 91,637 & 2,939 \\
\hline $\begin{array}{l}\text { Manager and site } \\
\text { assistant manager }\end{array}$ & 51,410 & 1,462 & 58,646 & 1,052 \\
\hline $\begin{array}{l}\text { Construction } \\
\text { supervisor }\end{array}$ & 50,933 & 272 & 116,579 & 1,566 \\
\hline $\begin{array}{l}\text { Administrative } \\
\text { personnel }\end{array}$ & 126,716 & 1,622 & 42,814 & 138 \\
\hline TOTAL & 575,474 & 141,068 & 613,843 & 153,720 \\
\hline
\end{tabular}

Source: Construction Industry Development Board, Malaysia (2017) 
This circumstance has forced the employer to hire low skilled foreign workers. Abdullah (2015) claimed that, foreign workers are willing to work in any conditions and accept small wages. This view also concurs with Abdul-Aziz (2001) that the utilization of foreign workers by construction companies in Malaysia because of willing to work extra hours, obedient, willing to receive low wages and flexible and mobile. The statistics on construction wages and salaries in 2017 from CIDB showed that the average daily wage for local skilled labour is between RM 70.00 and RM 120.00; whereas semi-skilled workers earn between RM 60.00 and RM 100.00. The rate for foreign workers is lower, with skilled labour earning between RM 50.00 and RM 100.00 and semi-skilled foreign workers earning between RM 40.00 and RM 80.00. Average wages for unskilled workers are much lower - between RM 25.00 and RM 30.00. The willingness and wide availability of foreign workers make the employer easily hiring them and at the end it will give significant impact on construction quality and productivity. This approach provides a short-term solution to the skilled workers shortage problem but has resulted in a long-term reliance on foreign workers for operation and maintenance for completed projects as well as future projects (Nguyen, 2015).

\section{Methodology}

This research presents the findings of the preliminary survey, which adopted the qualitative approach through a semi-structured interview. This semi-structured interview consists of several questions aimed to identify the availability of local skilled construction workers at construction sites. Semistructured interviews are one of the most dominant and widely used methods of data collection within the social sciences (Bradford \& Cullen, 2012). Semi-structured face-to-face interviews were exploited to obtain demographic data and to also identify the numbers of labour and issues related to the employing local labour in construction industry.

A total of ten participants (site supervisory staff) from five construction sites involved in the interview process. All the selected site big scale project because the value of the project is exceeding ten million Ringgit Malaysia. While the participants are selected based on their experience (more than five years) in the industry. Inputs from the construction participants and their views are needed in obtaining the real issues concerning the issues of hiring local labour in construction industry. The transcription and interpretation from the semi-structured interview findings have been carried out by using Atlas.ti 8( qualitative software. The data were collected in October 2017 until November 2017 which took one month to complete.

\section{Result and Discussion \\ Project background}

Table 4 shows the details of the project background. The interviews were asked to give the feedback on estimated value of the project, the starting and completion year, location of the project and the progress of work during interview session. The findings that emerge from the interview as follows: 
INTERNATIONAL JOURNAL OF ACADEMIC RESEARCH IN BUSINESS AND SOCIAL SCIENCES Vol. 10, No. 3, March, 2020, E-ISSN: 2222-6990 @ 2020 HRMARS

Table 4: Project Background

\begin{tabular}{lccccc}
\hline $\begin{array}{l}\text { Project } \\
\text { Description }\end{array}$ & Hospital (A) & Hospital (B) & Hospital (C) & School & Condominium \\
\hline Value & 286 million & 104 million & 350 million & 47 million & 108 million \\
\hline Duration & $2014-2018$ & $2016-2019$ & $2016-2017$ & $2015-2018$ & $2016-2019$ \\
\hline Location & Kelantan & Kelantan & Johor & Selangor & Kuala Lumpur \\
\hline Progress & Finished & Substructure & Finished & Finished & $\begin{array}{c}\text { Superstructure } \\
\text { \&ork }\end{array}$ \\
& Work & & Work & Worished \\
& & & & & Work \\
\hline
\end{tabular}

There were three types of projects involve for this research, namely; hospitals, school and condominium. The projects are compared in term of value, duration, location and progress of work. Based on the results, all the projects have a contract value of more than ten million which have been implemented by Grade 7 (G7) contractor registrations under CIDB. This projects also is considered as big scale projects. Concerning the projects duration, majority of the projects have contract duration within three years except for Hospital (C) only two years. The location of the project is two at Kelantan and others at Selangor, Kuala Lumpur and Johor. Four (4) of the projects are at the finishes stage and one at substructure stage. The progress of project also affected the numbers of the workers availability on the site. Each activity requires a different number of labours depends on the activity of works on site for example substructure and superstructures stage. Project completion also considers if need to complete speedily than the project acquires to hire more labours or used sophisticated technology.

Table 5 illustrates the number of workers for each project. Hospital (A) employed the highest number of employees and the lowest was a school project. It shows that the variable's value of project as stated previously in Table 4 and numbers of labour correlated each other. This is because Hospital $(A)$ is the highest project value amongst these five projects and employed 447 totals of labours. School is the lowest project value and hired only 97 of labours. Besides, the construction of hospital was more complicated compared to the school was only standard design. Other than that, the progress of work also influences the number of workers at the site. Refer to tables 4 and 5, during the interview session, the progress of work was finishing work for Hospital A, C, school and condominium showing there were highest number of workers on site. Total workers for all these five sites are 1351. There are only 415 local skilled workers and 936 foreign workers. The amount of local skilled workers was halved compared with foreign workers. It is $69 \%$ of foreign workers compared with local workers. This is supported by Abdul Hamid (2011) had also conducted a survey to sixteen construction sites at Johor Bahru found that only 409 local workers and 1130 foreign workers. 
INTERNATIONAL JOURNAL OF ACADEMIC RESEARCH IN BUSINESS AND SOCIAL SCIENCES Vol. 10, No. 3, March, 2020, E-ISSN: 2222-6990 @ 2020 HRMARS

Table 5: Numbers of labour

\begin{tabular}{|c|c|c|c|c|c|c|}
\hline Project / Description & $\begin{array}{l}\text { Hospital } \\
\text { (A) }\end{array}$ & $\begin{array}{l}\text { Hospital } \\
\text { (B) }\end{array}$ & $\begin{array}{l}\text { Hospital } \\
\text { (C) }\end{array}$ & $\begin{array}{c}\text { Schoo } \\
1\end{array}$ & $\begin{array}{c}\text { Condominiu } \\
\mathrm{m}\end{array}$ & TOTAL \\
\hline Total labour & 447 & 107 & 400 & 97 & 300 & 1351 \\
\hline Local Skilled labour & 182 & 53 & 50 & 30 & 100 & 415 \\
\hline Foreign labour & 265 & 54 & 350 & 67 & 200 & 936 \\
\hline \multicolumn{7}{|c|}{ Skilled labour from Technical Institution } \\
\hline $\begin{array}{l}\text { Malaysian } \\
\text { Construction } \\
\text { Academy (ABM) }\end{array}$ & 3 & - & - & 4 & 43 & \\
\hline $\begin{array}{l}\text { Institut Kemahiran } \\
\text { MARA (IKM) }\end{array}$ & 10 & - & - & - & - & \\
\hline $\begin{array}{l}\text { Institut Kemahiran } \\
\text { Belia Malaysia } \\
\text { (IKBM) }\end{array}$ & 46 & 3 & - & - & - & \\
\hline $\begin{array}{l}\text { Institut Latihan } \\
\text { Kemahiran Awam }\end{array}$ & 23 & - & - & -- & - & \\
\hline Kolej Komuniti & 68 & - & - & & - & \\
\hline Others & - & - & $\begin{array}{l}\text { Experienced } \\
\text { (50) }\end{array}$ & - & - & \\
\hline
\end{tabular}

Projects Hospital (C) hired 350 foreign labours but only 50 of local labours. It shows that all these five projects relied on foreign labour to execute the works. Based on the Table 5, since Hospital (A) employed the highest numbers or labours and employed skilled workers from TVET institutions. Three projects had hired skilled labours from ABM. It shows that, employer had trusted skilled labour from ABM. However, Hospital (C) only stated that their hired experience workers but did not specify from which institution there were from or there were possibilities that they have no qualifications needed but they have been exposed with long working experience in the field. And now they are needed due to their vast experience in the industry.

\section{Current Issues Related of Local Skilled Labour in Construction Project}

The current issue related with local skilled workers is when typing in the google search engine, it will appear about shortage of local skilled workers and over reliance to foreign workers. It shows that both were related to each other. Proven in Table 5 shows the proportion of both where there are more foreign workers rather than local workers. Meanwhile, Table 6 presents the issues related to the local labour in construction industry. There are four main issues identified such as local labour request for higher wages, demand to work at the supervisory level, incompliance with industry regulation and the employer expectation high skills and experience from the labour. Three of the respondents mentions that, the difficulties to hire local labour because of the local skilled labour demand for higher wages to work at construction site. This is supported by Manap et al., (2017) was conducted research to G7 contractors in Johor on strategies to attract the local skilled labour. The result revealed the first ranking were salary increments followed by allowance and overtime payment. The third rank has indicated that additional incentive such as bonus or reward from the 
INTERNATIONAL JOURNAL OF ACADEMIC RESEARCH IN BUSINESS AND SOCIAL SCIENCES

Vol. 10, No. 3, March, 2020, E-ISSN: 2222-6990 (C) 2020 HRMARS

employer could be one of the motivation factors that attracts the workers. It is supported by Burton (2012) increment in salary is the main motivation in attracting workers to work.

Furthermore, the local skilled labour demand for supervisory level in regards with their qualification. These issues will be related to salary. If the labour has a higher qualification, their perception was, they will work at a higher position and earn a higher salary to suit with their qualification. This situation was highlighted by Ismail et al., (2013) when a survey was conducted to 187 firms in Malaysia. The result revealed that there is a significant and positive relationship for variables wage rate and job category, where is if the wage rate for the supervisory increase the demand for this job category also will be raised by 0.054 percent. These studies concluded the main determinants of labour demand in various categories are rates wages and outputs. Both variables are positively related to labour demand for all categories of labour (Ismail et al., 2013).

Furthermore, on the reason of the client's demand for the experience workers. There were evidences that the site management has faced the problems to coach the fresh graduates even though they were fully trained by the TVET institutions due to time constrain on site. Real nature of works on site are different to what have been exposed in TVET institution. Other than that, perception of local labour towards working on site will be labelled as foreign worker was sometimes misled by this perception need to be corrected. 
INTERNATIONAL JOURNAL OF ACADEMIC RESEARCH IN BUSINESS AND SOCIAL SCIENCES

Vol. 10, No. 3, March, 2020, E-ISSN: 2222-6990 @ 2020 HRMARS

Table 6: Current issues related of local skilled labour in construction project

\begin{tabular}{|c|c|c|c|c|c|}
\hline $\begin{array}{l}\text { Project / } \\
\text { Description }\end{array}$ & Hospital (A) & Hospital (B) & Hospital (C) & School & $\begin{array}{c}\text { Condominiu } \\
\mathrm{m}\end{array}$ \\
\hline $\begin{array}{l}\text { Difficulty to } \\
\text { hire labour }\end{array}$ & Difficult & Difficult & Difficult & Difficult & Difficult \\
\hline $\begin{array}{l}\text { Reason of } \\
\text { Difficulty }\end{array}$ & $\begin{array}{c}\text { Due to } \\
\text { permit issue }\end{array}$ & $\begin{array}{l}\text { - Demand for } \\
\text { higher Wages. } \\
\text { - Education. } \\
\text { Negotiate for } \\
\text { better } \\
\text { compensation/ } \\
\text { allowance. }\end{array}$ & $\begin{array}{l}\text { - TVET graduates } \\
\text { become } \\
\text { supervisory level. } \\
\text { - Avoid same level } \\
\text { as Foreign } \\
\text { labour. }\end{array}$ & $\begin{array}{l}\text { - Demand } \\
\text { for higher } \\
\text { Wages. } \\
\text { - Not } \\
\text { enough } \\
\text { experienc } \\
\text { e. }\end{array}$ & $\begin{array}{l}\text { - Demand for } \\
\text { higher } \\
\text { Wages. } \\
\text { - Green Card } \\
\text { \& E Card. }\end{array}$ \\
\hline $\begin{array}{l}\text { Method of } \\
\text { hiring } \\
\text { labour }\end{array}$ & $\begin{array}{l}\text { - Through } \\
\text { supply } \\
\text { agency. }\end{array}$ & $\begin{array}{l}\text {-Hire skills } \\
\text { instead of } \\
\text { character. } \\
\text {-Provide } \\
\text { training to } \\
\text { workers. } \\
\text { - Keep in touch } \\
\text { with skilled } \\
\text { workers. }\end{array}$ & $\begin{array}{l}\text { - Connection with } \\
\text { previous project. } \\
\text { - Recommendatio } \\
\text { n from others. }\end{array}$ & $\begin{array}{l}\text { - Link with } \\
\text { IKBN or etc } \\
\text { - Hire based } \\
\text { on trade } \\
\text { need e.g. } \\
\text { IBS } \\
\text { installation. }\end{array}$ & $\begin{array}{l}\text { - Fresh and } \\
\text { training the } \\
\text { workers. }\end{array}$ \\
\hline $\begin{array}{l}\text { Requiremen } \\
t \text { to hire } \\
\text { labour }\end{array}$ & $\begin{array}{l}\text { - Skilled \& } \\
\text { experiences } \\
\text { - Rate of } \\
\text { labour } \\
\text { - willing to } \\
\text { work over } \\
\text { time }\end{array}$ & $\begin{array}{l}\text {-Written } \\
\text { Contract } \\
\text { - Resume }\end{array}$ & $\begin{array}{l}\text { - Increase } \\
\text { manpower to } \\
\text { complete job on } \\
\text { the given time } \\
\text { period. } \\
\text { - Increase profit } \\
\text { by hiring cheap } \\
\text { labour. }\end{array}$ & $\begin{array}{l}\text { - Need high } \\
\text { qualificatio } \\
\text { n. }\end{array}$ & $\begin{array}{l}\text { - Skilled \& } \\
\text { experience } \\
\text { s } \\
\text { - Full } \\
\text { certificate } \\
\text { request by } \\
\text { Governmen } \\
\text { t }\end{array}$ \\
\hline $\begin{array}{l}\text { Current } \\
\text { situation of } \\
\text { labour }\end{array}$ & Shortage & Shortage & Sufficient & Shortage & Shortage \\
\hline $\begin{array}{l}\text { Skilled } \\
\text { Required }\end{array}$ & $\begin{array}{l}\text { - Carpentar } \\
\text { y } \\
\text { - Bar } \\
\text { bender } \\
\text { Plastering }\end{array}$ & $\begin{array}{l}\text {-Communicatio } \\
\text { n Skills } \\
\text { - Multitasking \& } \\
\text { Teamwork } \\
\text { - Problem } \\
\text { Solving }\end{array}$ & $\begin{array}{l}\text {-Project } \\
\text { management } \\
\text {-Leadership } \\
\text {-Safety } \\
\text { Awareness }\end{array}$ & $\begin{array}{l}\text {-Electrical } \\
\text { Work } \\
\text { - Mechanical } \\
\text { Work } \\
\text {-Finishing } \\
\text { Work }\end{array}$ & $\begin{array}{l}\text { - Carpentary } \\
\text { - Bar bender } \\
\text { Plastering }\end{array}$ \\
\hline
\end{tabular}

Since the employer declared that the difficulty in hiring local workers, the next question asked that, how they employ labour. Normally the employer through their previous project will keep their 
contact for their next project and recommendation from others friend. Respondents from School Project also responded that they kept in network with TVET institutions to appoint the labour based on the skills and trade. Respondent from Condominium Project responds that they are willing to employ new and fresh graduated and trained them based on the real site conditions.

Recently, regarding with the requirement of labour that the employer want to hire. The priority is a skills, experiences and qualification, willing to work overtime and independent to do work with stipulated time given. This result was supported by Short et al., (2014) that indicates experience as one of the most important qualifications for new hires. This is the typical scenario that is happening nowadays in our country no matter what industry we are working in. They prefer to hire someone with lots of experience to reduce their time in training them and wanted to hire someone young as it is easier to deal with as they are still new in working condition. They also think it is best to employ graduates from TVET that has been taught and trained about the necessary skills that are required when they join the construction industry. These graduates are also more knowledgeable, as basic understanding of the work and the world of construction that have been taught and exposed to them.

Four out of five interviewees revealed on the shortage of labour. It is contradicted with the interviewee from Hospital (C) that mentioned there is enough labour employ in their construction site. This is due to the urgency to complete the work where the construction period is only one year. At the same time this project heavy dependence on foreign workers to complete the job. Finally, the construction site really needs carpentry, bar bender and plasterer based on the respondents from two projects. Other than that, skills needs are electrical work, mechanical work, finishing work. Besides, the skills labour also acquire to equip themselves with soft skill which are leadership, communication skills, multitasking, teamwork and problem solving.

Communication is one of the important skills required in all occupations. Communication is a method used to give and receive information, as well as to convey our ideas and opinions to those around us. To an employer, excellent communication skills are essential. Employers consistently ranked that excellent communication skills to be placed at the top of the list for potential employees. Short et al., (2014) have also agreed on communication skills especially soft skill, were among the top choices from employer point of view. This is the indication of the importance industry places on this area. This was supported by the main findings of the study conducted by Makhbul et al., (2007), which showed that the greatest performance gap for graduates nowadays are the communication skill and interpersonal skill. This shows that the employers' perception of graduates who are currently working with them have not yet reached the level of the required skills as they expected.

\section{Conclusion}

This research briefly presented the statistic of labour involved in the construction projects. Most of the sites really need the local skilled labour but it is very difficult to hire mainly because of the demand for higher wages. Findings from this research proved that, the construction industry are uniqueness in characteristics. Every project has a different character, even though it is similar category of building. Thus, the requirements of labour in each project are dissimilar. Recently, the industry had faced with the difficulty to hire local skilled labour to work in construction project. Consequently, the 
industry declared that shortage of labour in the industry. But it was quickly replaced by foreign workers. This is due to the availability of foreign workers and willingness of them to work in 3D's industry. The employers had admitted that this situation happened because the foreign workers accept low wages offered to them. Indirectly it's will maximise the employer's profit. This situation needs to be changed by giving priority to local workers. The limitation of this research is only conducted to five construction projects only. It is can be extended to more projects or only focused on one type or category of building. In conclusion the performance of the building mainly relied on the workmanship of skilled labour. Therefore, qualified local skilled workers are required to achieve clients' dream. On top of that, it is also can achieve value for money to the clients in obtaining excellent quality of building with minor defects. This is importance to ensure the performance of the building throughout the life span of the building.

\section{References}

Abdullah, H., Azam, M., \& Abdullah, M. Z. (2015). The Impact of Foreign Labour on the Unskilled Labour Demand in Malaysia. Mediterranean Journal of Social Sciences, 7(1), 264-273. https://doi.org/10.5901/mjss.2016.v7n1p264

Abdul-Aziz, A. R. (2001). Foreign Workers and Labour Segmentation in Malaysia's Construction Industry. Construction Management and Economics 19 (8), 789-798

Hamid, A. R., Singh, J. B. S. B., \& Mazlan, M. S. (2013). The Construction Labour Shortage in Johor Bahru, Malaysia. International Journal of Research in Engineering and Technology, Vol. 02 Issue 10, pp. $508-512$.

Hamid, A. R., Singh, B., Yusof, M. A., \& Abdullah, N. A. M. (2011). The Employment of Foreign Workers at Construction Sites. 2011 2nd International Conference on Construction and Project Management, 15(August 2014), 126-130. https://doi.org/10.1007/s004420050840

Aun, L. H., \& Leng, K. Y. (2018). Counting Migrant Workers in Malaysia: A Needlessly Persisting Conundrum. Researchers at ISEAS - Yusof Ishak Institute Analyse Current Events. ISSUE: 2018 No. 25 ISSN 2335-6677

Awe, E. M., Stephenson, P., \& Griffith, A. (2010). Impact of vocational training on skilled labour shortage within Nigerian construction sector. Paper presented at the CIB World Congress 2010, May $10-13$, Salford Quays, UK.

Bheemaiah, K., \& Smith, M. J. (2015). Inequality, Technology and Job Polarization of the Youth Labour Market in Europe. doi: 10.2139/ssrn.2615605

Bradford, S., \& Cullen, F. (2012). Research and research methods for youth practitioners. London: Routledge.

Burton K. (2012). A Study of Motivation: How to Get Your Employees Moving. SPEA Honors Thesis Spring 2012 Indiana University

CIDB. (2016). Contractor Registration requirements And Procedures Handbook. Contractors and Levy Division Construction Industry Development Board Malaysia (CIDB)

CIDB. (2017). Malaysia Country Report. 22th AsiaConstruct Conference Seoul, Korea

CIDB. (2015). Construction Monitor Employment Quarterly Report 3. Construction Monitor, Employment (Q3 2015), 24.2 Retrieved from http://www.cidb.org.za/publications/Documents/Construction Monitor - October 2015.pdf 
INTERNATIONAL JOURNAL OF ACADEMIC RESEARCH IN BUSINESS AND SOCIAL SCIENCES

Vol. 10, No. 3, March, 2020, E-ISSN: 2222-6990 @ 2020 HRMARS

CIDB. (2015). ACT 520, 1994. The Commissioner of Law Revision, Malaysia Under the Authority Of The Revision Of Laws Act 1968, 2015.

Edwards, R., and Holland, J. (2013). What is qualitative interviewing? Bloomsbury Publishing Plc, Great Britain.

Economic Planning Unit, (2015). Strategy Paper 9: Transforming Technical and Vocational Education and Training to Meet Industry Demand. Economic Planning Unit, Prime Minister's Department.

Flick, U. W. E. (2009). An introduction to qualitative research. London: SAGE Publishing.

Hussien, M. R. (2016). Reducing Unnecessary Regulatory Burdens on Business: Construction, Malaysia Productivity Corporation: Recommendation Report.

Ismail, R., \& Yuliyusman, F. (2014). Foreign labour on Malaysian growth. Journal of Economic Integration, 29(4), 657-675.

Ismail, R., Osman Z., \& Yuliyusman. (2013). Analisis Penentu Permintaan Buruh Firma di Malaysia. Prosiding Persidangan Kebangsaan Ekonomi Malaysia Ke VIII 2013. 888 - 897 ISSN: 2231-962X

Juliani, J., \& Yusof, Z. M. (2011). Human Resources in Malaysian Construction Industry, 2nd International Conference on Business and Economic Research (2nd ICBER 2011) Proceeding Human, 1762-1767.

Nasir, A. M. N., Ali, D. F., Noordin, M. K., \& Nordin M. S. (2011). Non-technical skills for technical skills workers in Malaysia. Proceedings of the IETEC'11 Conference, Kuala Lumpur, Malaysia

Nguyen, T. V., \& Galil, O. M. (2015). A Recommended Approach to Improve the Utilization of Local Labor in the Middle East Megaprojects. 2015 International Conference on Industrial Engineering and Operations Management. https://doi.org/10.1109/IEOM.2015.7093879

Manap, N., Noh, M. N. H., \& Syahrom, N. (2018). Recruitment criteria and attraction strategies for local trained labour in Malaysia's construction industry. IOP Conference Series: Earth and Environmental Science, 109(1). https://doi.org/10.1088/1755-1315/109/1/012011

Makhbul Z. M., \& Hasun F. M. (2007). Amalan pengambilan dan pemilihan pekerja: Tinjauan ke atas firma terpilih di sektor perkilangan International Journal of Management Studies. 14 (2) $143-$ 162

Mike, C. (2015). UNESCO TVET strategy 2016-2021: report of the UNESCO-UNEVOC virtual conference. UNESCO International Centre for Technical and Vocational Education. ISBN: 97892-95071-83-4

Odesola, A. I., \& Idoro, G. I. (2014). Influence of Labour-Related Factors on Construction Labour Productivity in the South-South Geo-Political Zone of Nigeria. Journal of Construction in Developing Countries, 19(1), 93-109, 2014 (C) Penerbit Universiti Sains Malaysia,

Mohamed, R. B. (2015). Manpower needs in construction. Retrieved from http://umpir.ump.edu.my/13055/1/FKASA - RAZLINA BINTI MOHAMED - CD 9742.pdf

Majid, M. A., Yusoff, W. F. M., \& Sapian, A. R. (2015). Women as Skilled Labour in the Construction Industry of Malaysia: Potential and Constraints. E-Proceeding of the International Conference on Social Science Research, 8(9), 167-177.

Mohd-Rahim, F. A., Mohd-Yusoff, N. S., Chen, W., Zainon, N., Yusoff, S., \& Deraman, R. (2016). The challenge of labour shortage for sustainable construction. Journal of Planning Malaysia, (5), 77-88. 
INTERNATIONAL JOURNAL OF ACADEMIC RESEARCH IN BUSINESS AND SOCIAL SCIENCES

Vol. 10, No. 3, March, 2020, E-ISSN: 2222-6990 @ 2020 HRMARS

Short, K. M., Pearce, A. R., Fiori, C. M., Bulbul, T., \& McCoy, A. (2014). The Influence of Internship Participation on Construction Industry Hiring Professionals When selecting New Hires and Determining Starting Salaries for Construction Engineering Graduates (121st ASEE Annual Conference \& Exposition, American Society for Engineering Education.

Sweet, S., \& Meiksins, P. (2017). Changing contours of work: Jobs and opportunities in the new economy (3rd ed.). Los Angeles: SAGE.

Triki, N. M. M. (2010). A critical assessment of the technical and vocational education and training programme for the Libyan chemical industry. Edinburgh Napier University. Retrieved from http://researchrepository.napier.ac.uk/4280/.

Uchitelle, L. (2009). Despite Recession, High Demand for Skilled Labor. The New York Times. Retrieved from http://www.nytimes.com/2009/06/24/business/24jobs.html.

Windapo, A. O. (2016). Skilled labour supply in the South African construction industry: The nexus between certification, quality of work output and shortages. SA Journal of Human Resource Management.

Zaki, S. A., Mohamed, S. F., \& Yusof, Z. M. (2012). Construction skilled labour shortage - The challenges in Malaysian construction sector. OIDA International Journal of Sustainable Development, 4(5), 99-108. 